\title{
THE COMPARISON OF THE SPRAY-DRYING AND FREEZE-DRYING TECHNIQUES FOR CAMEL MILK: A REVIEW
}

\author{
Ukilim Tastemirova ${ }^{1},{ }^{*}$ Inga Ciprovica ${ }^{2}$, Azaret Shingisov ${ }^{3}$ \\ ${ }^{1}$ Almaty Technological University, Kazakhstan \\ ${ }^{2}$ Latvia University of Life Sciences and Technologies, Latvia \\ ${ }^{3}$ M.Auezov South Kazakhstan State University, Kazakhstan \\ *Corresponding author's email: inga.ciprovica@llu.lv
}

\begin{abstract}
The aim of the present study was to analyse and compare camel milk powder quality and functional properties produced with spray-drying and freeze-drying techniques. Freeze-drying is recognized as an advanced method for the production of high-quality dried products, but it has been a costly process for production of camel milk powder. Spray-drying and freeze-drying of camel's milk demonstrated that the nutritional characteristics of this product basically remained unchanged compared to fresh milk. The differences were found analysing flowability, solubility and hygroscopicity of camel milk powder samples obtained with freeze-drying and spray-drying technique. Analysed quality indices of camel milk demonstrated that spray-drying has lower impact on camel milk powder physical properties in comparison with freeze-drying.
\end{abstract}

Key words: camel milk, spray-drying, freeze-drying.

\section{Introduction}

In 2018, the world market for camel milk products reached the value of 5.64 billion USD, growing of 3.89\% during 2011-2018 (Camel dairy market ...., 2019). The camel milk price is significantly higher compared to cow milk, as production of camel milk is lower, but production costs are higher. Nutritional benefits of camel milk significantly outweigh the production costs.

Camel milk is nutritiously dense product, characterises with lower fat and cholesterol, and higher protein content. Milk contains more whey proteins such as lactoferrin and immunoglobulins. On average, camel milk consists of more protein than cow milk. Milk is rich with an essential amino acids, which have beneficial influence on human health. Camel milk has several times more vitamin $\mathrm{C}$ and iron than cow milk (Singh et al., 2017). Some authors have established that the size of casein micelles and fat globules differs from cow milk (Farah \& Fisher, 2004; Thomas, Scher, $\&$ Desobry, 2004). Clinical studies have shown that camel milk has a positive influence on children with autism spectrum disorder (Adams, 2013). Also, it was established that consumers with lactose intolerance easily metabolized lactose with lower incidence level (Singh et al., 2017).

Camel milk products have been slowly gaining popularity across the world. Camel milk processors are also diversifying products which can be produce from camel milk. It is expected that global camel milk dairy market will grow up to $8.01 \%$ during 2020 2024, reaching 8 billion USD (Camel dairy market ..., 2019).

The main reason for production of camel milk powder is to prolong the shelf-life of product and to facilitate product storage and handling. The drying method of camel milk influences solubility of powdered product. The shelf-life of camel milk powder is around 12 months, but skimmed milk powder more than 2 years (Farah \& Fisher, 2004). The shelf-life of milk powder is established to warrant safety and to keep sensory properties like aroma and flavour. Milk powder is microbiologically stable product but some physicochemical properties like lactose crystallisation, particles caking, oxidation of fat, and Maillard reaction may occur during the shelf-life. Changes which occur during milk powder storage influence physical and functional properties, reconstitution process as well as emulsifying and foaming properties. The level of changes is strongly dependent on the storage conditions: temperature, relative air humidity and storage time. The understanding of changes that occur during milk powder production and storage will be valuable to predict the behaviour of milk powder during reconstitution process (Thomas, Scher, \& Desobry, 2004).

In practice, spray-drying is used for camel milk powder production but in recent years freeze-drying is practised for camel milk functional properties' preservation.

The aim of the present study was to analyse and compare camel milk powder quality and functional properties produced with spray-drying and freezedrying techniques.

\section{Materials and Methods}

The monographic method was used to summarise and analyse the latest information and research articles dedicated to camel milk drying. The published data were used for compilation of commercially available dairy products made from freeze-dried camel milk; in addition, the physical properties of camel milk powder were studied for reconstituted milk products production. 


\section{Results and Discussion}

Freeze and spray drying are processing methods which convert milk into powder. Each method affects the physicochemical characteristics of dried milk. Spray drying is a widely used drying method, because a very short time of heat contact and high rate of evaporation are needed that give a high-quality product with a relatively low cost. Freeze-drying is a process in which water is removed from a frozen solution by sublimation. Due to the vacuum, the ice will evaporate immediately without turning into water, and this ensures that all solid compounds will be considered as the costliest process for production of dried products (Kim, Chang, \& Kwan, 2010; Rogers et al., 2008; Carvalho et al., 2007; Boss et al., 2004; Tsinontides et al., 2004). Freeze-drying is applied for drying heat sensitive foods and biologically active compounds. This process minimizes the degradation reactions and maintains adequate physical, chemical and biological stability of the product during longterm storage (Fonseca et al., 2004). Freeze-drying is recognized as an advanced method for production of high-quality dried products.

The main quality criteria of milk powder is solubility, flowability, hygroscopicity and water activity, these parameters are compared in Table 1.

The freeze-dried camel's milk showed higher insolubility compared to spray-dried camel milk. Insolubility usually must be below $0.2 \mathrm{ml}$ in good quality milk powder (CODEX STAN, 1999). Hausner ratio varied from 1.15 to 1.31 and from 1.21 to 1.37 , correspondingly. Hausner ratio results are strong connection to powder flowability, a ratio of 1 to 1.25 indicated that powder had acceptable flowability, but ratio from 1.25 to 1.4 demonstrated rather well flowability (Sulieman et al., 2018). All established values fall within free powder particles flowing. Also, powders differ in hygroscopicity. Hygroscopicity characterises the ability of dried product to absorb water molecules from environment. The hygroscopicity of studied powders also diverse, freeze-dried powders had more hygroscopicity which could be explained with structure of powder's particles and higher bulk density. Analysed quality indices of camel milk demonstrated that spray-drying has lower impact on camel milk powder physical properties.

The camel milk powder composition is summarized in Table 2.

Nutritional properties of freeze-dried camel's milk remained unchanged compared to raw milk (Ibrahim \& Khalif, 2014).

The comparison of differently produced camel milk powder microstructure was provided in the review. Dried milk particles obtained with spraydrying technique showed average size conglomerates which consist of small merged sub-units (Figure 1a). Dried milk particles obtained with freeze-drying technique showed large size conglomerates which

The influence of different drying techniques on camel milk powder quality

\begin{tabular}{|c|c|c|c|c|}
\hline Drying technique & Insolubility, $\mathrm{ml}$ & Hausner ratio & $\mathrm{a}_{\mathrm{w}}$ & Hygroscopicity \\
\hline Spray-drying* & $0.35-0.50$ & $1.21-1.37$ & $0.154-0.210$ & $20.43-20.47$ \\
\hline Freeze-drying** & $0.65-0.85$ & $1.15-1.31$ & $0.253-0.340$ & $22.32-27.32$ \\
\hline Standard requirements*** & $\leq 0.20$ & -- & -- & -- \\
\hline
\end{tabular}

* Sulieman et al., 2014

**Sulieman et al., 2018

***CODEX STAN 207-1999

The comparison of differently produced camel milk powder composition (Sulieman et al., 2014; Sulieman et al., 2018)

\begin{tabular}{|l|c|c|c|}
\hline \multirow{2}{*}{\multicolumn{1}{|c|}{ Indices }} & \multicolumn{2}{|c|}{ Drying technique } & \multirow{2}{*}{ Standard requirements*** } \\
\cline { 2 - 3 } & Spray-drying & Freeze-drying & $\geq 95.00$ \\
\hline Total solids content, \% & $98.94-98.99$ & $97.00-97.56$ & $\leq 5.00$ \\
\hline Moisture content, \% & $1.01-1.94$ & $2.44-3.00$ & $\leq 25.00$ \\
\hline Protein content, \% & $24.10-26.73$ & $23.54-25.30$ & $\leq 26.00$ \\
\hline Fat content, \% & $27.86-29.82$ & $21.25-22.96$ & \\
\hline
\end{tabular}




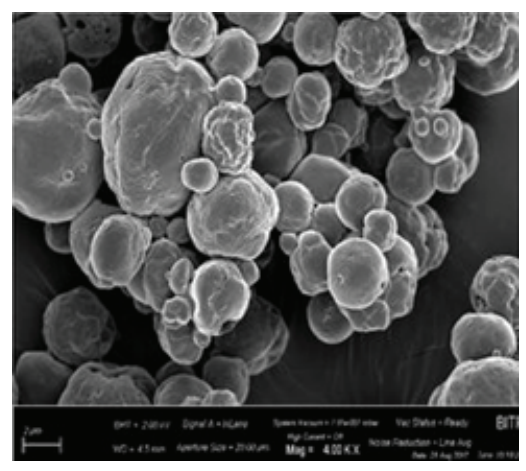

$a^{*}$

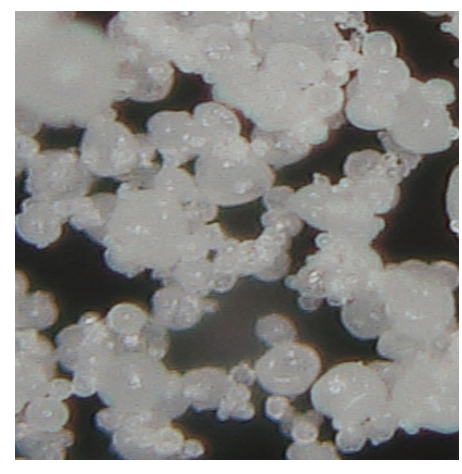

$\mathrm{b}^{* *}$

Figure 1. The microstructure of camel milk powder. a - spray-dried (Ho et al., 2019)

$\mathrm{b}-$ freeze-dried (authors unpublished materials) *electronic microscopy, **3D microscopy.

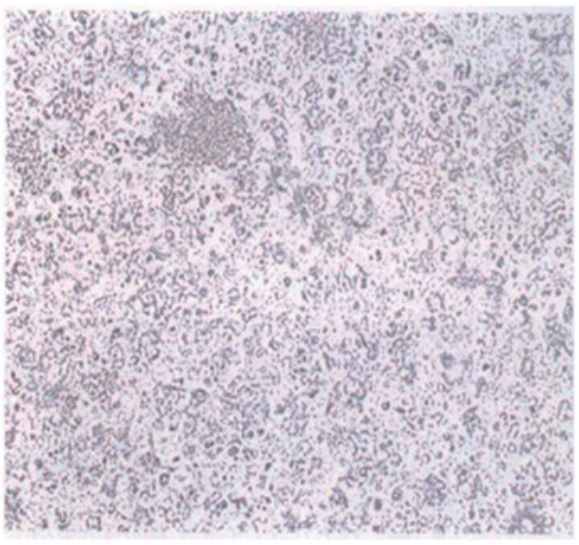

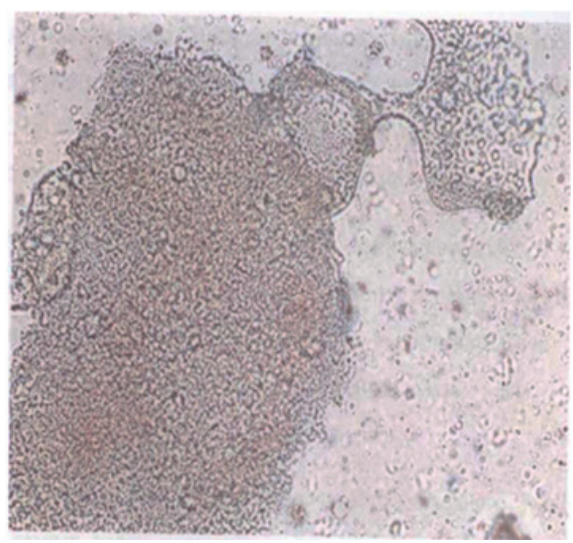

$\mathrm{b}$

Figure 2. The microstructure of reconstituted milk (Simonenko, Manuilov, \& Sidorova, 2019). $\mathrm{a}$ - spray-dried, $\mathrm{b}$ - freeze-dried.

consist of many small merged units in bigger network (Figure 1b).

The results showed that camel milk powder had amorphous structure and spherical particles produced by spray drying. Freeze-dried milk consists of rough, regularly and irregularly shaped, and very voluminous particles. The microstructure analysis of camel milk powder confirms that drying process influences milk particles and their solubility (Kulazhanov et al., 2014).

The reconstituted milk samples microstructure is shown in Figure 2.

The microstructure results showed that spraydried milk reconstitution provide the full dispersion of milk constituents with the formation of homogeneous consistence (Figure 2a). The study of freeze-dried milk microstructure revealed that milk particles are hardly disintegrated (Figure 2b) and full solubility had not been achieved. The reconstituted milk microstructure analyses showed the formation of large size conglomerates and the considerable coalescence of fat globules.

\section{Conclusions}

Freeze-drying is recognized as an advanced method of the production of high-quality dried products, but this process has been a costly process for production of camel milk powder.

Spray-drying and freeze-drying of camel's milk demonstrated that the nutritional value and chemical composition of this product basically remained unchanged compared to raw milk.

The differences were found analysing flowability, solubility and hygroscopicity of camel milk powder samples obtained with freeze-drying and spray-drying technique.

\section{References}

Adams, C.M. (2013). Patient report: autism spectrum disorder treated with camel milk. Global Advance in Health and Medicine, 2(6), 78-80. 
Akers, M.J., Fites, A.L., \& Robinson, R.L. (1987). Types of parenteral administration. Journal of Parenteral science and technology, 41, 88-95.

Boss, E.A., Filho, R.M., \& Toledo, E.C. (2004). Freeze-drying process: real time model and optimization. Chemical Engineering and Processing, 43, 1475-1485.

Camel Dairy Market: Global Industry Trends, Share, Size, Growth, Opportunity and forecast 2019-2024 (2019). p. 142.

Carvalho, A.S., Silva, J., Ho, P., Teixeira, P., Malcata, F.X., \& Gibbs, P. (2007). Relationship between solubility of freeze-dried skim milk and death of freeze-dried Lactobacillus delbrueckii spp. bulgaricus during storage. Milchwissenshaft, 62, 148-150.

CODEX STAN 207-1999 (1999). Codex standard for milk powders and cream powder.

Farah, Z., \& Fisher, A. (2004). Milk and meat from the camel: Handbook on Products and Processing. Zurich: Vdf Hochschulverlag AG an der ETH Zurich, p. 230.

Fonseca, F., Passot, S., Cunin, O., \& Marin, M. (2004). Collapse temperature of freeze-dried Lactobacillus bulgaricus suspensions and protective media. Biotechnology Progress, 200, 229-238.

Ho, T.M., Chan, S., Yago, A.J.E., Shravya, R., Bhandari, B.R., \& Bansal, N. (2019). Changes in physicochemical properties of spray-dried camel milk powder over accelerated storage. Food Chemistry, 295, 224-233.

Ibrahim, A.H., \& Khalif, S.A. (2014). Effect of freeze-drying on camels milk nutritional properties. International Food Research Journal, 22(4), 1438-1445.

Kim, S-H., Chang, Y-H., \& Kwak, H-S. (2010). Physicochemical properties of reconstituted milk made from freeze-dried milk powder or spray-dried milk powder. Korean Journal of Food Science of Animal Resources, 30, 28-35.

Kulazhanov, K.S., Aralbayev, N.A., Dihanbayeva, F.D., Serikbayeva, A.D., \& Yusof, Y.A. (2019). The study of solubility and density of camel milk powder, obtained by freeze-drying. Вестник АТУ, 3 (124), 47-51.

Rogers, S., Wu, W.D., Saunders, J., \& Chen, X.D. (2008). Characteristics of milk powders produced by spray freeze drying. Drying Technology, 26, 4040-412.

Simonenko, S.V., Manuilov, B.M., \& Sidorova, E.V. (2019). Most efficient method of drying combined milk. International Research Journal, Vol. 1, 9 (87), 116-121.

Singh, R., Mal, G., Kumar, D., Patil, N.V., \& Pathak, K.M.L. (2017). Camel milk: and important natural adjuvant. Agricultural Research, 6, 327-340.

Sulieman, A.M., Elamin, O.M., Elkhalifa, E.A., \& Laleye, L. (2014). Comparison of physicochemical properties of spray-dried camel's milk and cow's milk powder. International Journal of Food Science and Nutrition Engineering, 4(1), 15-19.

Sulieman, A.M., Elamin, O., Elkhalifa, E.A., \& Laleye, L. (2018). A comparative study of physicochemical properties of freeze-dried camel's milk and cow milk powder. Journal of Agriculture and Food Science, $6(2), 11-16$.

Thomas, M.E.C., Scher, J., \& Desobry, S. (2004). Milk powder ageing: effect on physical and functional properties. Critical Reviews in Food Science and Nutrition, 44 (5), 297-322.

Tsinontides, S.C., Rajniak, P., Pham, D., Hinke, W.A., Placek, J., \& Reynolds, S.D. (2004). Freeze drying principles and practice for successful scale-up to manufacturing. International Journal of Pharmacy, 280, $1-16$. 